\title{
Biomass universal district heating systems
}

\author{
Victor Manuel Soltero ${ }^{1}$, Salvador Rodríguez-Artacho ${ }^{2}$, Ramón Velázquez ${ }^{3}$, \\ Ricardo Chacartegui ${ }^{3, *}$ \\ ${ }^{1}$ Department of Design Engineering, University of Seville, Seville, 41011, Spain \\ ${ }^{2}$ Department of Constitutional Law, National University of Distance Learning, Madrid, Spain \\ ${ }^{3}$ Department of Energy Engineering, University of Seville, Seville, 41092, Spain
}

\begin{abstract}
In mild climate regions Directive 27/2012 EU application for developing sustainable district heating networks in consolidated urban nucleus is a challenge. In Spain most of the municipalities above 5,000 inhabitants have a reliable natural gas network and individual heating systems at homes. In this work a new heating network paradigm is proposed, the biomass universal heating network in rural areas. This model involves all the economic, legal and technical aspects and interactions between the different agents of the systems: provider company, individual and collective end-users and local and regional administration. The continental region in Spain has 588 municipalities with a population above 1,500 inhabitants close to forest biomass with renewable use. In many of these cases the regulation identifies the ownership of the forest resources use. The universal heating networks are a great opportunity for energy saving of $2,000 \mathrm{GWh}$, avoiding 2.7 million tons of $\mathrm{CO} 2$ emissions and with a global annual savings for end users of 61.8 million of euros. The presented model is easily extrapolated to other small municipalities in Europe. The real application of the model is presented for three municipalities in different locations of Spain where Universal Heating Networks are under development. The analysis show the interest of the integrated model for the three cases with different structural agents and relationships between them. The use of sustainable forest resources, extracted and managed by local companies, strengths circular economy in the region with a potential global economic impact above $200 \mathrm{M} €$.
\end{abstract}

\section{Introduction}

The Energy Efficiency Directive (EED - 2012/27/EU) (1) establishes a common framework for the promotion of energy efficiency within the European Union, to ensure the achievement of the European Union headline target of $20 \%$ on energy efficiency by 2020 .

A barrier for district heating (DH) development is the lack of a sectorial regulation for allowing public or private domain use for thermal infrastructures, similar to the existing sectorial regulation for water and electricity (2). For massive implementation of heating networks in consolidated urban nucleus is required a development model integrated for all participating agents. Although optimized networks can result in high environmental, economic, social benefits $(3,4)$ they must be adequately evaluated and identified by all participating agents in order to assure optimized development and maximizing these

\footnotetext{
*Corresponding author: ricardoch@us.es
} 
benefits and the sustainability of the system. In 2015 there were more than 5,000 district network systems in Europe (5). The level of development of district heating networks in Europe varies strongly from an intense presence in Norther and Central Europe to scarce introduction in Southern regions, even when there is interesting potential for their application. This is the case of Spain, where there is an incipient interest in District Heating and Cooling (DHC). Currently there are 240 urban heating and/or cooling networks, of which 202 are officially registered. Most of these of DH/DHC networks correspond with demonstration systems, with a mean length below $1.5 \mathrm{~km}$, of which almost half $(47 \%)$ are public sector networks, and with very little commercial technology development (6).

The first option for implanting DH/DHC systems is the use of surplus heat from nearby power plants and industries for residential heating. In Spain however, medium and large size industries -which can provide a cost-effective surplus energy - are in most cases located too far from urban areas, and it is not feasible in most cases to take advantage of this surplus heat for the residential sector. For covering this demand two different and complementary ways can be followed for new DH/DHC installations in Spain: Biomass District heating networks(7) and Natural gas District heating networks (4). Potential for biomass heating networks in Spain is high in the continental region, however it has not been developed. This is due to the risk and uncertainties due to legal and regulatory gap for their development combined with adequate models for their development. In this paper are analysed all the subsystems and agents participating in the promotion and development biomass district heating and they are integrated in a holistic model for optimizing the benefits adapted to the local situation. The model is applied to the continental region in Spain

\section{Legal sectorial framework for services infrastructures}

Within the EU, it is already pointed out that $\mathrm{DH}$ network need to be seen and considered as Services of [Economic] General Interest -SEIG-, entering a specific category of services already envisaged for other traditionally monopolistic services such as gas, electricity, water or telecommunications. When referring to the economic difficulties linked to financing infrastructure building and deployment, the gap between sectors is substantial and relevant. In this sense, a comparison between an already existing legal framework for those traditional sectors and the lack of such a framework specifically for $\mathrm{DH}$ is an obstacle which better sooner than later, should be removed. Otherwise, competitiveness among sectors that should share the same market rules will never occur in fair and just proportion. So has it been pointed out by European Commission in (8) when highlighting that governments could -and should- do much more to leverage the inequality among infrastructure deployments rules and legal framework. It concludes that public intervention is reasonable and justified since it has been a fact in the past. Accordingly, it states that "this has been routinely done in the past for network providers by effectively the granting or auctioning of licenses and this could readily be applied to district heating networks, or indeed any other form of energy infrastructure". More precisely, some competitive disadvantages should be remove. Not by means of eliminating those advantages that traditionally were put in place in order to help out infrastructure financing in order to meet deployment goals and plans. To the contrary, by means of compensating DH projects with the same tools from which others sector have been benefiting from the past. As it is stressed in the report, "incumbent utility suppliers such as gas and electricity pipe and cable networks have a huge competitive advantage over would-be competitors piped heat suppliers by virtue of the various rights such as pre-granted planning permission, ground and road breaking rights, not enjoyed by DH operators". Consequently, if a more fair and well-balance scenario is to be built for all infrastructure players -irrespective of the type of 
infrastructure- then those same rights traditionally recognized to former incumbents " must be created and assigned in some way to CHP-DH developers if private capital is to create these networks" . It is a matter of jus balancing the unfair treatment. Otherwise, private sector might not have the financial muscle for engaging significant investment. A final remark made by the report states that "unless this is recognized by the EU and remedied, CHP-DH networks will not be built on the scale envisaged as part of the programme to combat climate change and reduce energy dependence". This leads us to the exercise of identifying what elements of those sectorial laws and regulations are common to different sectors so that we can guess a similar content when and if a DH Services Law/Directive was ever foreseen.

\section{Universal biomass heating network}

In previous section has been presented a context of challenging/non fully developed regulation for district heating systems as for other energy services. In this work is defined a new holistic approach for identifying and optimize the interaction between the multiple agents participating within the district heating. This concept is the Universal biomass heating network. It optimizes the global performance of the system defining the requirements/ interactions and participating agents. It can be defined as a thermal energy generation, distribution and selling system characterized by:

- Universal access for all end-users. Any end-user must have access to the network assuming the payment of the connection and individual preparation costs.

- Investors and promoters assume commercial risks and in counterpart are the owners of the system and exploitation profits.

- System is based on local biomass as fuel. It assures sustainability in the whole process of extraction, transport and operation and promotes circular economy.

- Local administration regulates and supports the global system with regulation, licences and as consumer.

- End user access in free market conditions and quality of supply is warranted by contract with the operator/promoter

- Specific regulation/rules/contracts warranty sustainability of the system and the circular economy in the region

A universal biomass district heating can be modelled as a System where there are four main Subsystems: i) forestry resource, ii) techno-economic, iii) commercial and iv) regulator. Interaction and articulation between them is presented in Fig.1.

i) Forestry resource subsystem. Fuel is defined by the availability, homogeneity, recurrence, ownership, price and quality. It is the main pillar around which is developed the biomass heating system. The ownership of the resource and the manager of mountain will be the agents who develop functional relationships with other agents.

ii) Regulatory subsystem. It supports and provides legal stability and safety to the global system. While it is desirable a sectorial normative for $\mathrm{DH}$, in many cases it is not developed and systems are regulated by local authorities with environmental and urbanistic competences. For the case under analysis, biomass forestry, the legal subsystem should interact with the mountain manager for assuring supply and maintenance. However this interaction is not always possible because forestry use and biomass recollection/exploitation are adjudicated by economic auction without linking both actors.

iii) Commercial subsystem. It includes the structure of relationships between the Universal District Heating and the end-user. The agents are the end-users and the investor/network developer. It includes economic issues but also agreements in supply quality, service, availability and after sales service including maintenance aspects. 
iv) Techno-economic subsystem. Includes design process, detailed engineering, economic and environmental viability analyses and financing. It links the participating agents, the investor/promoted of the Biomass Universal District Heating and the municipalities.
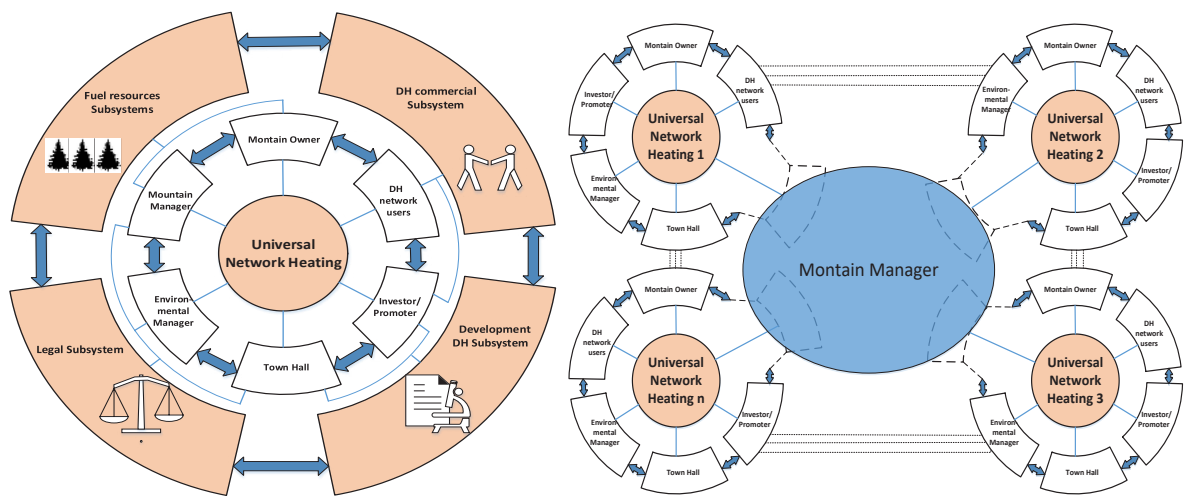

Fig. 1. a) Universal Network Heating model (left). b) Integrated management between different universal heating networks of the forestry resource (right).

\section{Biomass universal district heating agents}

The agents participating in the Universal Biomass District Heating networks, BioUnivDH, are related in a hierarchal dependence of the four subsystems and they interact dynamically between them. Depending on the country, region or area under of study they can be a set of independent organisms or involved competences can be grouped in one single organism, as is the case of Spain, with Mountain manager and Environmental manager. The following agents are identified in each Biomass Universal Heating Network:

-Forestry resource manager. It has assigned the management of the mountain (independently of the public or private ownership). In Spain is done via the law on Mountains/Forest Act. They have the role of mountain planning and exploitation approval. It launches the processes for treatment and exploitation of the forestry resource. They are regional entities with the vision about recurrent and sustainable production capacity of the forestry resource. Integral management requires the redistribution of resource from areas with excess in production to those with unsatisfied demand, Fig. 1 b. In the cases based only on the direct public auction there are difficulties for the development of structured redistribution strategies based on general interest criteria.

-Owner of the forestry resource. Ownership can be public or private. In the case of public ownership with a volume enough for fuel supplying, the system eliminates development and operation risks because the warranty of supply and price. In addition a circular economy is generated from forestry exploitation for heating self-consumption as it combines mountain maintenance and exploitation for covering heating demand.

-Environmental Manager. He supervises and emits the environmental authorization for the generation central. It constrains the urbanistic authorization of the Municipality to evaluation of emissions derived from combustion (NOx, soots) and noise levels.

-Municipality. It has the competences on urbanistic licenses and local regulation. Sometimes if it is also the owner of the soil. It eases the development of the project collaborating/participating with promoters. It also can have competences on taxes, which can be used as support of the network construction. It has an economic counterpart from the installation exploitation because of the uses of subsoil for network spreading. Municipality participation is required for an adequate development and exploitation of the system. Besides, in occasions, Municipality is the owner of the forestry resource. Municipalities are 
the main channel supporting the social interests on the project and they can use it as a tool for social energy policy (i.e. for energy poverty fighting policy measures).

-Universal district heating users. In rural environments three main categories of customers can be identified as function of energy requirements and use: permanent users, second residence users (weekends and holidays) and singular buildings. The first group is highly affected by energy costs and depending on the area even by energy poverty, as happens in different rural areas in Spain, meanwhile, in the second group, priority aspects are comfort and availability. Singular public buildings (schools, ambulatory, sport centres, administrative buildings) and singular private buildings (hotels, commercial buildings...) have an energy demand estimated in the range of $8-15 \%$. Generally their incorporation to the heating network is easier due to the professional management of the energy bill. All these users are expecting a fixed price without oscillation which will result in more than $10 \%$ of savings after their integration in a biomass heating network. Their main investments are the connection costs and the equipment for heat exchange and measure. One of the main social challenges for new networks development is the social acceptance of the heating central location.

-Promoter/investor. They can be public or private promoters. The promoter assumes the investment risk and all the risks of project: regulatory, commercial, resource availability. In some cases, public promoters have difficulties for assuming commercial risks and the end users management.

\section{Potential for application in continental region of Spain}

For the application of the concept of BioUnivDH the continental region of Spain is considered, Fig.2, including all those villages with a population in the range of 1,000 10,000 inhabitants, and disregarding the villages with existing natural gas networks. It implies a set of 501 municipalities. The development of biomass universal district heating systems to cover these municipalities is estimated in 3,744 M€ and it would affect to 1.6 million people, resulting in a global installed power of $8.3 \mathrm{GW}$ and an annual energy of 7,825 GWh, with an estimated CO2 emissions savings of 2,747 t. Main data of applying the model are given in table 1.
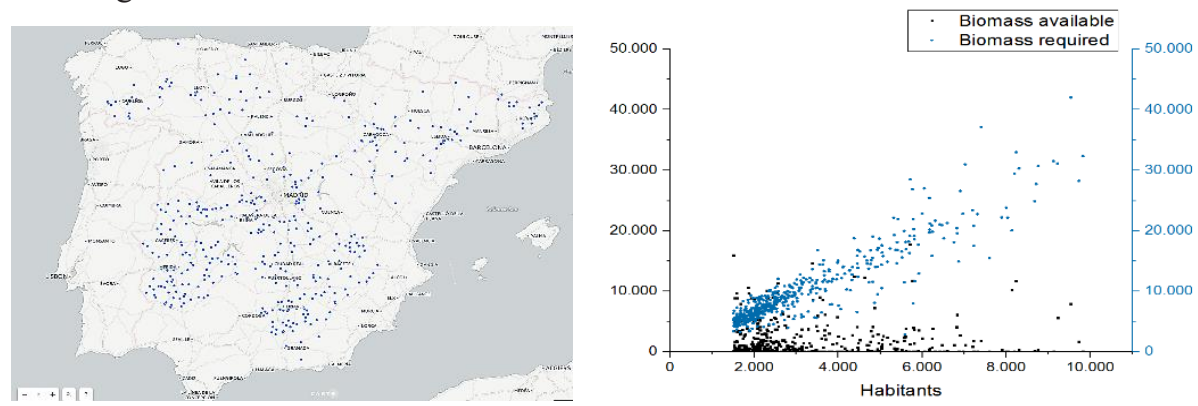

Fig 2. a) Case study area: 501 municipalities in continental area of Spain (right). b) Biomass required and available by village (left).

The required biomass for this set of universal biomass district heating is 5.2 million tons, meanwhile these municipalities only have within their territories 787,831 t (Fig. 2). However in the study region where these villages are located, the forestry biomass potential is 6.9 Mtons. This area considers the nearby municipalities disregarded within this study because population size or natural gas network installed make not sustainable the BioUnivDH installation. This circumstance between neighbour territories highlights the relevance of the role of the agent manager of the forestry resource in the redistribution of resource between the production areas and demand areas. 
Table 1. Municipalities under study and the expected impact of BioUnivDH

\begin{tabular}{|c|c|c|c|c|c|c|c|c|c|}
\hline Habitants & $\begin{array}{c}\text { Number of } \\
\text { villages }\end{array}$ & Users & $\begin{array}{c}\text { Invest } \\
\mathrm{M} €\end{array}$ & $\begin{array}{c}\text { Required } \\
\text { Biomas } \\
(\mathrm{t})\end{array}$ & $\begin{array}{c}\text { Available } \\
\text { Biomass }\end{array}$ & $\begin{array}{c}\text { Jobs } \\
\text { created }\end{array}$ & $\begin{array}{c}\text { Energy } \\
\text { Poverty } \\
\text { index (\%) }\end{array}$ & $\begin{array}{c}\text { Incomes } \\
\text { M } €\end{array}$ & $\begin{array}{c}\text { CO2 } \\
\text { savings } \\
(\mathrm{t})\end{array}$ \\
\hline$<2 \mathrm{k}$ & 131 & $228 \mathrm{k}$ & 558 & $737 \mathrm{k}$ & $197 \mathrm{k}$ & 1,229 & $10.67-50.28$ & 9.0 & $401 \mathrm{k}$ \\
\hline $2 \mathrm{k}-5 \mathrm{k}$ & 294 & $858 \mathrm{k}$ & 2,085 & $2,718 \mathrm{k}$ & $452 \mathrm{k}$ & 4,530 & $15.19-53.19$ & 33.3 & $1.497 \mathrm{k}$ \\
\hline$>5 \mathrm{k}$ & 76 & $498 \mathrm{k}$ & 1,100 & $1,592 \mathrm{k}$ & $138 \mathrm{k}$ & 2,653 & $12.81-46.44$ & 19.5 & $886 \mathrm{k}$ \\
\hline & $\mathbf{5 0 1}$ & $\mathbf{1 , 5 8 4} \mathbf{k}$ & $\mathbf{3 , 7 4 4}$ & $\mathbf{5 , 0 4 7} \mathbf{k}$ & $\mathbf{7 8 7} \mathbf{k}$ & $\mathbf{8 , 4 1 2}$ & $\mathbf{1 0 . 6 7 - 5 3 . 1 9}$ & $\mathbf{6 1 . 8}$ & $\mathbf{2 . 7 4 7} \mathbf{k}$ \\
\hline
\end{tabular}

A relevant result of the analysis is that in the rural areas under study a high percentage of end users are vulnerable to the risk of energy poverty, Fig. 3. It means that a population comprised between $10.67 \%$ and $53.19 \%$, dedicates more than $10 \%$ of their incomes to energy costs, meanwhile the mean value in Spain is $15 \%$. This situation is justified by the high price of fuel in these not well communicated rural areas, in most cases the use gasoil as fuel for heating, and the minor per capita incomes compared with cities and other regions. In this sense the development of a network of BioUnivDH can be a tool for a social policies, introducing bonuses in places with this combination of costs and incomes. Meanwhile currently there are no social bonuses for gasoil heating; the biomass universal district system could allow to introduce bonuses for low incomes families in a rational and controlled way. Different levels of support depending on the incomes and integrated within the municipal taxes or in the energy bill can be applied to families. Expected savings by end-users for these systems are $10 \%$ of energy costs. Considering the savings compared to individual heaters (amortization and maintenance), and discounting the funds dedicated to energy poverty fighting measures, the massive implementation of BioUnivDH in the region under study would allow annual incomes for the municipalities of $61.8 \mathrm{M} €$, Fig. 4. Biomass consumption would be $311.6 \mathrm{M} €$ in biomass, and estimated new jobs would be 8,412 , in activities of extraction, manipulating and drying of biomass, Fig. 3. It goes to local handwork, which implies that local economy would receive an economic activity above 200 M€. The extended implementation of BioUnivDH in the region would contribute to $2,747 \mathrm{t}$ $\mathrm{CO} 2$ savings. Besides it has additional environmental benefits. Currently biomass management is done only where there is direct demand and extraction costs are more competitive. In cases these management is done by public authorities. Intensity of these forestry maintenance treatments is limited by budget availability. The new market created by these systems would be a catalyser for spreading of viable forestry maintenance plans. Another environmental global benefit is associated to the local use of biomass, considering supply in a mean distance below $32 \mathrm{~km}$, and avoiding associated transport emissions (9).
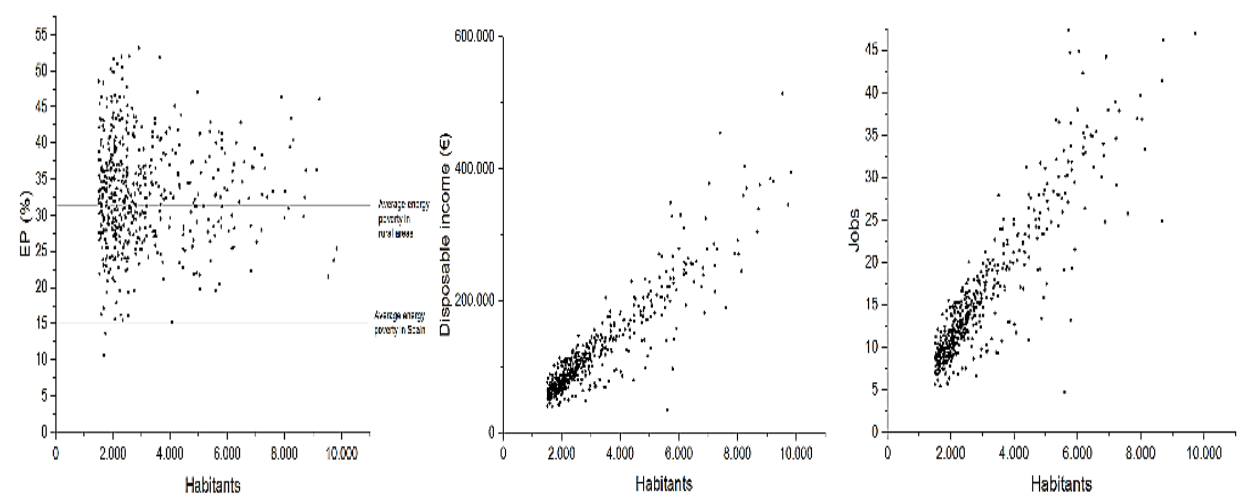

Fig. 3. a) Energy poverty index in the villages (left); b) annual incomes per muncipality (center); c) jobs (right) generated by each BioUnivDH system 


\section{Study cases}

In this section, the application of BioUnivDH is presented disaggregated in three rural municipalities with high forestry resource availability and in where currently universal biomass district heating BioUnivDH are under development, Table 2. They have high heating demand, in some cases with demands similar to central Europe cities. Currently they are using gasoil as main fuel for heating in individual boilers. They have been selected in three different regions of Spain: Municipality A is placed at the South of Spain, municipality $\mathrm{B}$ in the North meanwhile municipality $\mathrm{C}$ is locate in the central region.

Table 2. Main characteristics of the three municipalities under study BioUnivDH

\begin{tabular}{|l|c|c|c|}
\hline & Town A & Town B & Town C \\
\hline Habitants [ud] & 1,502 & 1,919 & 1,998 \\
\hline Fuel Poverty Index [\%] & 48.58 & 50.28 & 21.29 \\
\hline First houses [ud] & 530 & 745 & 770 \\
\hline Second houses [ud] & 294 & 305 & 775 \\
\hline Thermal Power [MW] & 7.91 & 10.11 & 10.53 \\
\hline Degree Days 20 based [ ${ }^{\circ} \mathrm{C} / \mathrm{y}$ ] & 3,439 & 4,133 & 3,359 \\
\hline Energy [MWh/y] & 10,090 & 15,063 & 13,281 \\
\hline Biomass required [t/y] & 6,312 & 9,306 & 8,316 \\
\hline Biomass avaiable [t/y] & 15,969 & 8,830 & 8,799 \\
\hline Network leght [m] & 4,792 & 8,456 & 11,905 \\
\hline Linear heat density [MWh/y·m] & 230.52 & 192.58 & 122.25 \\
\hline Invest [M€] & 2,9 & 4.2 & 5.0 \\
\hline Biomass Price $20 \% \mathrm{RH}[€ / \mathrm{t}]$ & 73.79 & 57.74 & 67.00 \\
\hline Biomass cost [k€/y] & 373 & 430 & 446 \\
\hline
\end{tabular}

Among these three cases there are great differences in the energy poverty index. Village $\mathrm{C}$, close to Madrid, has a high impact of second residence and tourism, which improves its economic activity and characteristics of energy demand. However in village $\mathrm{B}$, a high rate of unemployment combined with a high heating demand causes a very high level of energy poverty $50.28 \%$. For case A, there is biomass in excess, however, the difficult extraction of forestry in nearby mountains, compared with the other cases, implies that it has the highest biomass price, $73.79 € /$ t. By other side, this village has the highest building density, with a linear heat density of $230.52 \mathrm{MWh} / \mathrm{y} \cdot \mathrm{m}$, almost the double that the case $\mathrm{C}$. The required investments for implementing BioUnivDH in the municipalities under analysis have a wide dispersion, 2.9, 4.2 y 5.0 M€, due to differences in building densities. The participating agents in the BioUnivDH in these municipalities are presented in Table 3, showing the different participation and role of each one. Due to current regulatory framework in Spain, promoter is in charge of obtaining authorizations and establishing alliances with the rest of agents of the BIoUnivDH system in order to give sustainability to the global system. From the villages under analysis, only in case B where the forestry resource owners are the end users, price supply and circular economy is fully assured. Viability is promoted and supported by the municipalities by the integration of municipal buildings in the network. 
Table 3. BioUnivDH agents and system structure in the three municipalities under study

\begin{tabular}{|c|c|c|c|}
\hline & Town A & Town B & Town $\mathrm{C}$ \\
\hline Resource owner & Municipality $79 \%$ - Private $21 \%$ & $\begin{array}{l}\text { Citizens born in Municipality } \\
100 \%\end{array}$ & Municipality $86 \%$ - Private $14 \%$ \\
\hline Mountain Manager & $\begin{array}{l}\text { Natural park. Assignment of } \\
\text { exploitation because of } \\
\text { management. }\end{array}$ & $\begin{array}{l}\text { Regional Government. There is } \\
\text { no assignment of exploitation. } \\
\text { Management taxes }\end{array}$ & $\begin{array}{l}\text { Regional Government. } \\
\text { Assignment of exploitation } \\
\text { because of management. }\end{array}$ \\
\hline $\begin{array}{l}\text { Municipality } \\
\text { participation }\end{array}$ & $\begin{array}{l}\text { No land contribution for heating } \\
\text { generation central. } 5 \text { municipal } \\
\text { buildings with } 6 \% \text { of whole } \\
\text { heating demand. }\end{array}$ & $\begin{array}{l}\text { No land contribution for heating } \\
\text { generation central. } 8 \text { municipal } \\
\text { buildings with } 7 \% \text { of whole } \\
\text { heating demand. }\end{array}$ & $\begin{array}{l}\text { It contributes with land for } \\
\text { heating generation central. } 4 \\
\text { municipal buildings with } 5 \% \text { of } \\
\text { whole demand. }\end{array}$ \\
\hline $\begin{array}{l}\text { Environmental } \\
\text { manager }\end{array}$ & $\begin{array}{l}\text { Municipality Regional } \\
\text { government }\end{array}$ & $\begin{array}{l}\text { Municipality Regional } \\
\text { government. }\end{array}$ & $\begin{array}{l}\text { Municipality Regional } \\
\text { government. }\end{array}$ \\
\hline User & Saving in energy costs of $20 \%$. & $\begin{array}{l}\text { Saving in energy costs of } 18 \% \text {. } \\
\text { Assignment of exploitation with } \\
\text { additional } 5 \% \text { discount on } \\
\text { energy price. Circular economy. }\end{array}$ & Saving in energy costs of $15 \%$. \\
\hline Investor/developers & $\begin{array}{l}\text { Private with bank financing. It } \\
\text { manages licenses/authorizations } \\
\text { for network development, heat } \\
\text { generation central, } \\
\text { environmental impact. It } \\
\text { negotiates biomass supply by } \\
\text { providers. It manages heating } \\
\text { sales contracts with end users. }\end{array}$ & $\begin{array}{l}\text { Private with bank financing. It } \\
\text { manages licenses/authorizations } \\
\text { for network development, heat } \\
\text { generation central, } \\
\text { environmental impact. It } \\
\text { negotiates biomass supply by } \\
\text { end users. It manages heating } \\
\text { sales contracts with end users. }\end{array}$ & $\begin{array}{l}\text { Private with bank financing. It } \\
\text { manages licenses/authorizations } \\
\text { for network development, heat } \\
\text { generation central, } \\
\text { environmental impact. It } \\
\text { negotiates biomass supply by } \\
\text { providers. It manages heating } \\
\text { sales contracts with end users. }\end{array}$ \\
\hline
\end{tabular}

The role of each agent can vary, depending on the specific characteristics of the location, existing regulation and even social perception. To identify the role and benefit of each participant is a key activity for the successful development of a Bio UniveDH. Social, environmental and economic benefits of the implementation of these BioUnivDH in the selected rural locations are presented in table 4. The substitution of the current gasoil fuel boilers for heating by these biomass universal district heating network converts the heating global system in a global null $\mathrm{CO}_{2}$ emissions system. From the social point of view they allow social energy policy from the municipalities via bonuses on the energy bill depending on the family incomes. At the same it generates circular economy creating jobs and promoting an industry based on forestry exploitation and mountain maintenance. This synergy is increased in case B where the users are the owners and providers of the forestry resource.

Table 4. BioUnivDH impact of BioUnivDH in the three locations under study

\begin{tabular}{|l|c|c|c|}
\hline & Town A & Town B & Town C \\
\hline $\mathrm{CO}_{2}$ emissions save [t/y] & 3,435 & 5,064 & 4,526 \\
\hline Disposable income [k€/y] & 77 & 124 & 102 \\
\hline Economic benefits [k€/y] & 324 & 560 & 408 \\
\hline Jobs [ud] & 6 & 9 & 8 \\
\hline
\end{tabular}

\section{Conclusions}

This paper introduces the holistic approach for Universal Biomass District Heating development. It includes all the subsystems and agents involved in the installation and operation of a biomass district heating. It identifies the different roles and benefits for each participating agent and maximizes the whole system benefits, eliminating inefficiencies and barriers, as those related to absence of adequate sectorial regulations for heating networks or inadequate location of resources. The concept has been applied to the central region of Spain, where there are 501 villages with a population in the range 1,000-10,000 inhabitants and without a natural gas network supply. The analyses show that there is enough capacity for local biomass supply with an adequate interaction with neighbourhood territories where 
forestry biomass resources are currently under exploited because a reduced local demand. It shows the relevance of the mountain management role. The massive application of the concept to this region has a high potential for energy and $\mathrm{CO}_{2}$ emissions savings, creation of new direct incomes for municipalities and new jobs. The model estimates a global economic impact above $200 \mathrm{M} €$ in the region under a concept of circular economy. Three municipalities with the first UnivBioDH systems under construction in this region have been studied and compared, showing the role of the different agents depending of the specific characteristics of the villages and the sustainability of the integrated approach.

\section{References}

1. European Parliament, Off. J. Eur. Union Dir., 1-56 (2012).

2. C. Henry, M. Matheu, A. Jeunemaitre, Regulation of network utilities : the European experience (Oxford University Press, 2001).

3. J. Lizana, C. Ortiz, V. M. Soltero, R. Chacartegui, Energy (2016),

4. V. M. Soltero, R. Chacartegui, C. Ortiz, R. Velázquez, Energy. 115, 1513-1532 (2016).

5. C. Europe, COGEN Europe- European association for the promotion of cogeneration.

6. Spanish Heat and Cooling Companies Association Report ADHAC, 1-35 (2014).

7. V. M. Soltero, R. Velázquez, R. Chacartegui, M. Carvalho, J. A. Becerra, in Ecos $2015: 28$ th International Conference on Efficiency, Cost, Optimization, Simulation and Enviromental Impact of Energy Systems (2015).

8. D. Andrews et al., Background Report on EU-27 District Heating and Cooling Potentials, Barriers, Best Practice and Measures of Promotion. Report EUR 25289 EN (2012).

9. M. Manzone, A. Calvo, Renew. Energy. 108, 250-259 (2017). 